\title{
40. ORGANIC GEOCHEMISTRY OF QUATERNARY SEDIMENTS FROM DEEP SEA DRILLING PROJECT LEG 72, SOUTH ATLANTIC OCEAN ${ }^{1}$
}

Philip A. Meyers and Keith W. Dunham, Oceanography Program, Department of Atmospheric and Oceanic Science, The University of Michigan, Ann Arbor, Michigan

\begin{abstract}
Organic matter in sediments from Sites 515,516 , and 517 reflects a history of low marine productivity and of oxygenated bottom waters in the western South Atlantic since the Pliocene. Organic carbon contents are low, averaging $0.26 \%$ of sediment weight. Distributions of $n$-alkanes, $n$-alkanols, and $n$-alkanoic acids show evidence of microbial reworking, and $n$-alkanes contain important terrigenous contributions, presumably of eolian origin.
\end{abstract}

\section{INTRODUCTION}

Organic matter contained within oceanic sediments is a reflection of the sources and depositional processes that participated in the sediment accumulation. In particular, the amounts and types of sedimentary organic components are products of biological production in surface waters, supplemented by materials transported by winds and currents and altered by microbial and chemical processes during passage through the water column and after burial. Evidence of these many factors is often preserved in the elemental, isotopic, and molecular composition of sediment organic matter.

In order to identify the sources of organic matter in sediments and to characterize depositional paleoenvironments in the South Atlantic during the Neogene, sediment samples were obtained from three locations during DSDP Leg 72: in the Brazil Basin (Site 515, water depth $4250 \mathrm{~m}$ ), on the Rio Grande Rise (Site 516, water depth $1313 \mathrm{~m}$ ), and in the Vema Channel (Site 517, water depth $2963 \mathrm{~m}$ ). Analyses of organic carbon concentrations, organic $\mathrm{C} / \mathrm{N}$ ratios, and extractable lipid components were made. Both solvent-extractable (free) and alkaline hydrolyzeable (bound) lipid fractions were obtained, from which fatty acids, hydrocarbons, and fatty alcohols were separated.

\section{METHODS}

Five samples from the frozen organic geochemistry core sections from DSDP Sites 515, 516, and 517 (Fig. 1) were obtained. These muds were kept frozen until analysis. After the samples had been freeze-dried, their total carbon contents were measured with a Hewlett-Packard 185B CHN analyzer. Residual carbon was measured after $\mathrm{HCl}$ dissolution of carbonates and was considered to represent the total organic carbon content. Percent calcium carbonate was calculated from the difference between initial and residual carbon contents. Organic matter $\mathrm{C} / \mathrm{N}$ ratios were determined from residual carbon values. Percent organic carbon contents of the samples were calculated on a dry-weight basis for the original, carbonate-containing sediment.

A two-stage extraction procedure was used. Soxhlet extraction with toluene/methanol yielded the easily extracted, unbound fraction of materials present in the samples. A second extraction with $0.5 \mathrm{~N} \mathrm{KOH}$

\footnotetext{
${ }^{1}$ Barker, P. F., Carison, R. L., Johnson, D. A., et al., Init. Repts. DSDP, 72: Washington (U.S. Govt. Printing Office).
}

in methanol/toluene provided the hydrolyzeable, bound components. Both fractions were treated with methanolic boron trifluoride to convert fatty acids to their methyl esters, and then lipid subfractions were separated by column chromatography on alumina over silica gel. The classes so obtained contained alkanes and alkenes, aromatic hydrocarbons, fatty acid methyl esters, and hydroxy lipids, including sterols and alkanols. Hydroxy compounds were silylated with BSTFA before gas chromatography.

Splitless injection gas-liquid chromatography was employed to determine the types and amounts of compounds making up the lipid subfractions. A Hewlett-Packard 5880 FID gas chromatograph equipped with a $20 \mathrm{~m}$ SE54 fused silica capillary column was used with hydrogen as carrier gas. Quantification was attempted through the use of known amounts of internal standards added to each sample before column chromatography. Individual compounds were tentatively identified by retention times in this preliminary survey. Reported values have been corrected for laboratory contaminants and for mass discrimination over the wide molecular-weight ranges surveyed.

\section{RESULTS AND DISCUSSION}

\section{Organic Carbon and $\mathbf{C} / \mathbf{N}$ Values}

Concentrations of organic carbon in these Quaternary sediments are given in Table 1 . Their mean value is $0.26 \%$, which is in good agreement with means of $0.2 \%$ in modern deep-ocean sediments (Degens and Mopper, 1976) and of $0.3 \%$ in older samples from DSDP Legs 1 through 31 (McIver, 1975).

In view of the low organic carbon content of these Leg 72 samples, several paleoceanographic inferences can be made. First, the organic matter probably became incorporated into these sediments under oxygenated bottom water conditions, a situation not conducive to organic matter preservation (Hinga et al., 1979; Cobler and Dymond, 1980; Demaison and Moore, 1980). Second, the biological productivity of the surface waters of this part of the western South Atlantic was probably low throughout the Quaternary and the Pliocene. Both the low organic carbon values of all samples and the high carbonate concentrations at the shallower Sites 516 and 517 lead to this conclusion. Site 515 evidently is below the calcite compensation depth, and there has been a resulting loss of carbonate. Suess (1980) has noted that the flux of organic matter to the deep sea continually decreases with increasing depth, and Bishop and others (1978) have reported that the fraction of original organ- 


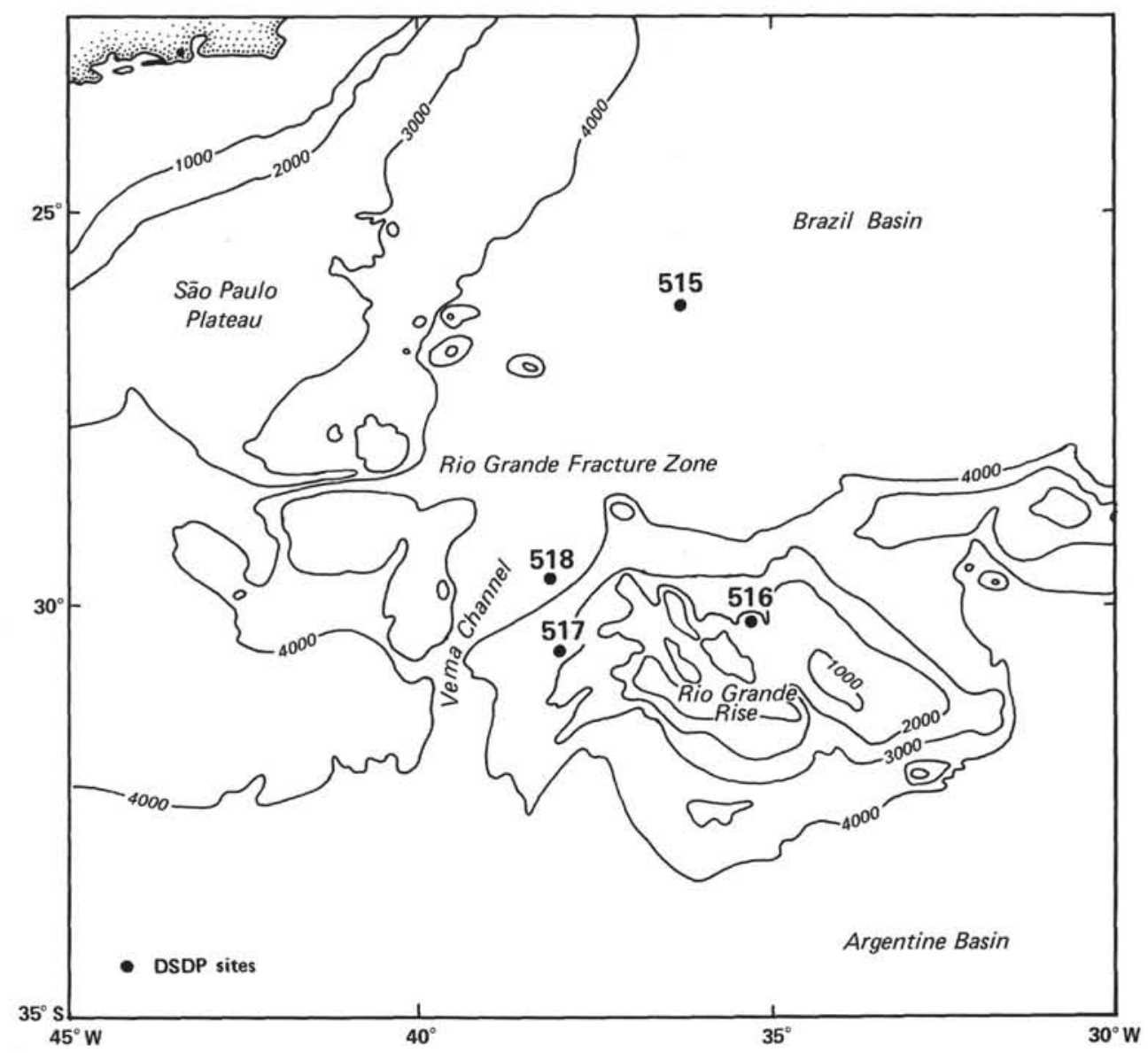

Figure 1. Locations of DSDP Sites 515, 516, and 517 in the western South Atlantic Ocean. Site 516 is on the Rio Grande Rise.

Table 1. General descriptions and organic contents of DSDP Leg 72 samples.

\begin{tabular}{|c|c|c|c|c|c|c|c|}
\hline $\begin{array}{l}\text { DSDP hole } \\
\text { (location) }\end{array}$ & $\begin{array}{l}\text { Water } \\
\text { depth } \\
\text { (m) }\end{array}$ & $\begin{array}{c}\text { Core-section } \\
\text { (interval in cm) }\end{array}$ & $\begin{array}{l}\text { Sub-bottom } \\
\text { depth } \\
\text { (m) }\end{array}$ & Age & $\underset{(\%)}{\mathrm{CaCO}_{3}}$ & $\begin{array}{c}\text { Organic } \\
\text { carbon } \\
(\%)\end{array}$ & $\begin{array}{l}\text { Atomic } \\
\mathrm{C} / \mathrm{N}\end{array}$ \\
\hline $\begin{array}{c}515 \text { (Brazil } \\
\text { Basin) }\end{array}$ & 4250 & $2-2,108-113$ & 42.1 & Quaternary & 7 & 0.43 & 9.6 \\
\hline $\begin{array}{l}\text { 515B (Brazil } \\
\text { Basin) }\end{array}$ & 4252 & $\begin{array}{l}3-4,140-150 \\
6-6,145-150\end{array}$ & $\begin{array}{l}119.8 \\
151.5\end{array}$ & $\begin{array}{l}\text { Pleistocene } \\
\text { Pliocene }\end{array}$ & 9 & $\begin{array}{c}0.23 \pm 0.03^{\mathrm{a}} \\
0.24\end{array}$ & $\begin{array}{l}6.9 \\
6.9\end{array}$ \\
\hline $\begin{array}{l}\text { 516A (Rio } \\
\text { Grande } \\
\text { Rise) }\end{array}$ & 1313 & $2-2,145-150$ & 6.5 & Pleistocene & 82 & 0.13 & 4.8 \\
\hline $\begin{array}{l}517 \text { (Vema } \\
\text { Channel) }\end{array}$ & 2963 & $4-2,135-141$ & 14.2 & Pleistocene & 58 & 0.28 & 19.2 \\
\hline
\end{tabular}

a Mean \pm standard deviation of 3 determinations.

ic matter reaching the bottom is smallest in areas of low productivity. Such areas commonly have low sediment accumulation rates, another factor working against preservation of organic matter in bottom deposits (Müller and Suess, 1979). The higher carbonate contents at Sites 516 and 517 imply relatively low opal contents. DiesterHaas (1978) includes high concentrations of organic carbon and of opal in sediments as indicators of high productivity caused by surface upwelling; low concentrations in these Leg 72 samples suggest low productivity.

Atomic $\mathrm{C} / \mathrm{N}$ ratios average 9.5 in the five samples, but samples from Holes 515B and 516A have atomic $\mathrm{C} / \mathrm{N}$ ratios substantially lower than this average. The lower values are similar to those found in DSDP Leg 58 sediments by Waples and Sloan (1980). Surficial marine sediments commonly have $\mathrm{C} / \mathrm{N}$ ratios between 9 and 18 (Stevenson and Cheng, 1972; Müller, 1977), so the low ratios may indicate greater diagenetic losses of carbon than of organic nitrogen. Müller (1977) cautions, however, that the presence of inorganic ammonium and of organic nitrogen compounds sorbed to clay minerals can produce artificially low $\mathrm{C} / \mathrm{N}$ ratios in organic-carbon-lean samples such as these. For this reason, $\mathrm{C} / \mathrm{N}$ ratios may not be reliable indicators of sources of bulk organic matter in these Neogene samples.

\section{Aliphatic Hydrocarbons}

The low concentrations of organic matter made reliable quantification of hydrocarbons difficult, and hence only qualitative data are given in this report. Distributions of free $n$-alkanes in samples from the Brazil Basin (Site 515), from the Rio Grande Rise (Site 516), and the Vema Channel (Site 517) are dominated by long-chain components, although the one from the Rio Grande Rise contains many shorter-chain $n$-alkanes (Fig. 2). Land plants commonly have hydrocarbon compositions dominated by $\mathrm{C} 27, \mathrm{C} 29$, and $\mathrm{C} 31 n$-alkanes, whereas algae contain mostly shorter-chain components in the $\mathrm{C} 16$ to C20 range (Simoneit, 1978). Quaternary sediments containing terrigenous hydrocarbon distributions like those at these locations have been reported at other DSDP sites, 

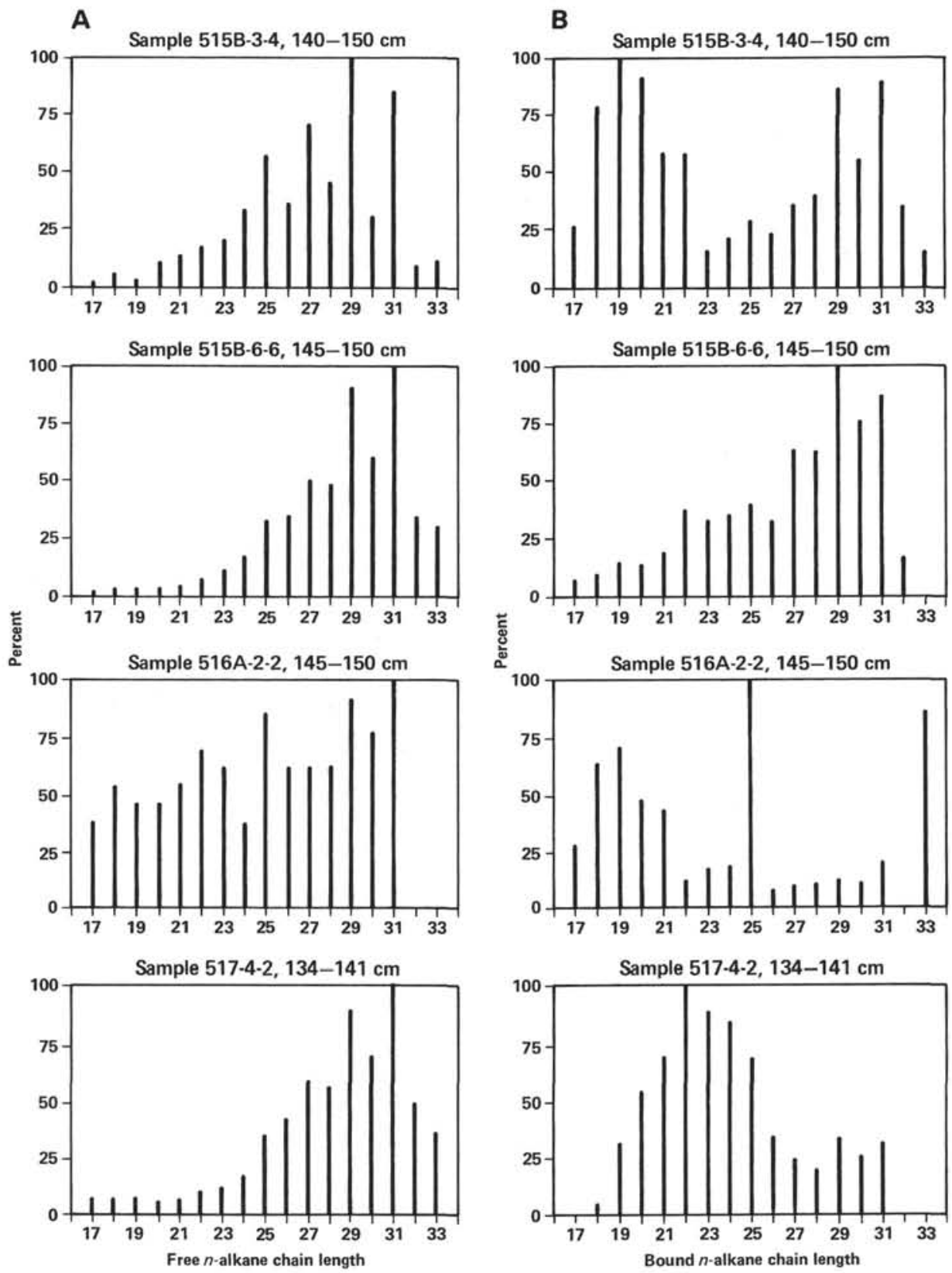

Figure 2. Distributions of free (A) and bound (B) $n$-alkanes normalized to major component and given as percentages of that major $n$-alkane.

including Sites 436 and 440 in Japan Trench (Brassell et al., 1980; Rüllkotter, Conford, et al., 1980); Sites 467, 469 , and 471 offshore of southern California (Rüllkotter et al., 1981; McEvoy et al., 1981; Simoneit and Mazurek, 1981); and Sites 487 and 491 in the Middle America Trench (Brassell et al., 1982). The dominant $n$-alkane in these examples is $n$-C29, but it is $n$-C31 in Quaternary samples from Site 362 on the Walvis Ridge (Boon et al., 1978 ) and Sites 442,443 , and 444 from the northern Philippine Sea (Rüllkotter, Flekken, et al., 1980). As seen in Figure 2, the major $n$-alkane in the samples from the Rio Grande Rise and from the Vema Channel is $n$ C31; either $n$-C29 or $n$-C 31 is the major free $n$-alkane in the Brazil Basin samples.
Downslope transport of land-derived materials may contribute to the hydrocarbon distributions found in the Brazil Basin, but it is difficult to envision how such input can be significant at Site 516 on the Rio Grande Rise or at Site 517 on the seaward slope of the Vema Channel (see Fig. 1). Transport of terrigenous hydrocarbons to these locations by eolian dusts is a more likely explanation. According to Simoneit's (1977) description of the lipid character of dust particles collected over the Atlantic Ocean, terrigenous components dominate. Furthermore, he finds latitudinal variations in $n$-alkane dominance: $n-\mathrm{C} 27$ is the major component in the North Atlantic, $n-\mathrm{C} 29$ in equatorial latitudes, and $n-\mathrm{C} 31$ in the South Atlantic. Because $n-\mathrm{C} 29$ and $n$-C 31 dominate $n$ - 
alkane distributions at Sites 515, 516, and 517, eolian input was evidently important to the hydrocarbon contents of sediments deposited in this region of low marine productivity.

At Site 516, both the free and the bound $n$-alkane compositions have more of an aquatic character than in other samples, perhaps the result of less degradation of marine organic matter during sinking (the water depth at this location is only $1313 \mathrm{~m}$ ). As observed by Suess (1980), loss of organic matter is directly related to sinking distance. The low organic carbon concentration $(0.13 \%)$ may be caused by dilution by the carbonate minerals, which make up $82 \%$ of the sediment weight at this Rio Grande Rise site (Table 1).

Chromatograms of free and bound hydrocarbons from Sample 515B-6-6, 145-150 cm are shown in Figure 3. This Pliocene sample, from a sub-bottom depth of $151.5 \mathrm{~m}$, is the oldest sample in this study. The free hydrocarbon fraction contains an unresolved complex mixture (UCM) peaking around $n-\mathrm{C} 29$, whereas the bound fraction exhibits no UCM. In the younger samples, a UCM peaking at about $n$-C20 was present in the bound fractions. None of the UCMs constituted more than half of the hydrocarbon fraction, and none of the hydrocarbon chromatograms resembled those of potential shipboard contaminants (cf. Doran and Johnson, 1979). Considering the shapes of the UCMs and their dissimilarity among samples of different ages, we think that they probably arose from microbial or possibly diagenetic processes rather than from contamination, and that they indicate detrital and reworked organic matter in these sediments.

Further evidence of microbial or diagenetic alterations of hydrocarbons is given in Table 2 , which gives ratios of various geolipid components. Pristane/phytane ratios less than 1 suggest deposition under anoxic conditions (Didyk et al., 1978). Because it is unlikely that this region of the western South Atlantic has expe-
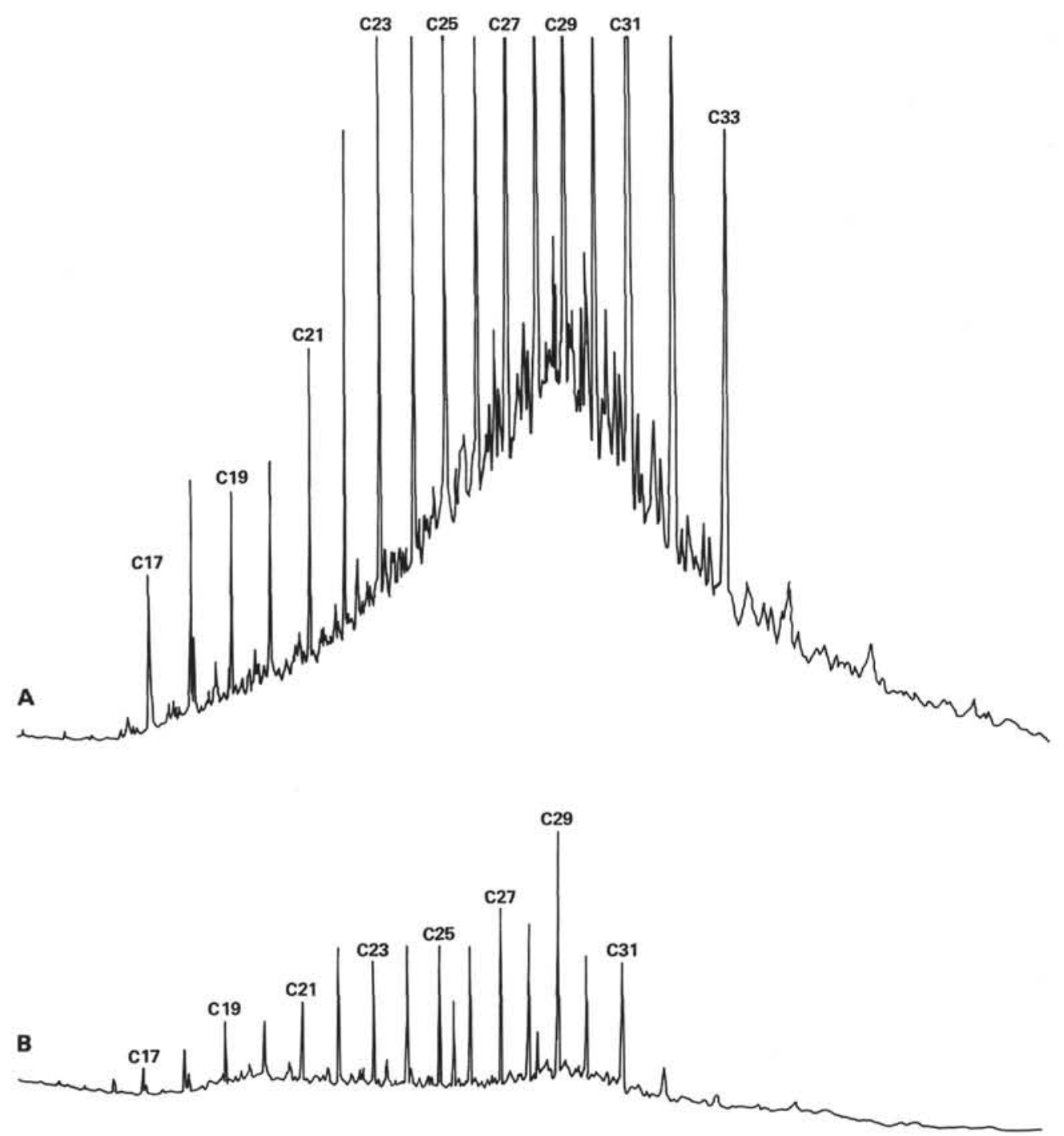

Figure 3. Chromatograms of free (A) and bound (B) hydrocarbons extracted from Sample 515B-6-6, $145-150 \mathrm{~cm}$. Major straight-chain alkanes are identified by number of carbon atoms. Gas chromatography conditions: $20 \mathrm{~m}$ SE54 glass capillary column, hydrogen carrier gas at $2 \mathrm{ml} /$ minute, $70-270^{\circ} \mathrm{C}$ at $4 \%$ minute. 
Table 2. Geolipid ratios of DSDP Leg 72 samples (hole-core-section, interval in $\mathrm{cm}$ ).

\begin{tabular}{|c|c|c|c|c|c|c|c|c|}
\hline \multirow[b]{2}{*}{ Geolipid fraction } & \multicolumn{2}{|c|}{$\begin{array}{c}515 B-3-4, \\
140-150\end{array}$} & \multicolumn{2}{|c|}{$\begin{array}{c}515 \mathrm{~B}-6-6 \\
145-150\end{array}$} & \multicolumn{2}{|c|}{$\begin{array}{c}516 \mathrm{~A}-2-2, \\
145-150\end{array}$} & \multicolumn{2}{|c|}{$\begin{array}{l}517-4-2, \\
135-141\end{array}$} \\
\hline & Free & Bound & Free & Bound & Free & Bound & Free & Bound \\
\hline \multicolumn{9}{|l|}{ Hydrocarbon ratios } \\
\hline Pristane/phytane & 0.63 & 0.46 & 0.75 & 0.38 & $<1$ & 0.46 & 1.27 & $<1$ \\
\hline Pristane/C17 $n$-alkane & 0.47 & 0.61 & 0.29 & 0.50 & & 0.44 & 0.57 & \\
\hline $\mathrm{C} 29 / \mathrm{C} 17 n$-alkanes & 68.6 & 1.07 & 50.1 & 14.3 & 2.22 & 0.44 & 13.0 & \\
\hline Odd/even $n$-alkanes & 1.83 & 1.09 & 1.40 & 1.27 & 1.23 & 1.64 & 1.22 & 1.08 \\
\hline \multicolumn{9}{|l|}{ Fatty acid ratios } \\
\hline C26/C16 n-acids & 0.18 & 0.49 & 0.03 & 1.59 & & 0.54 & 0.07 & 0.20 \\
\hline Even/odd $n$-acids & 6.42 & 6.85 & 25.71 & 6.73 & & 8.39 & 3.54 & 11.9 \\
\hline \multicolumn{9}{|l|}{ Alkanol ratios } \\
\hline C26/C16 $n$-alkanols & 0.92 & & 0.33 & 1.00 & & 0.29 & 1.20 & 0.50 \\
\hline Even/odd $n$-alkanols & 3.08 & & 5.36 & 8.15 & & 1.05 & 4.45 & 8.75 \\
\hline
\end{tabular}

rienced anoxia during the Quaternary or late Tertiary, the low pristane/phytane ratios in Table 2 cannot be reliable indicators of past bottom water conditions. The low pristane $/ n$-C17 ratios suggest microbial contributions, as do the low ratios of odd-to-even $n$-alkanes. Overall, these hydrocarbon ratios indicate that these organic-carbon-lean sediments contain predominantly reworked, detrital hydrocarbons. The most probable source is from land, a conclusion based upon the dominance of long-chain $n$-alkanes in Figure 2 and the high $n-\mathrm{C} 29 / n-\mathrm{C} 17$ ratios in Table 2.

\section{Fatty Acids}

Distributions of free and bound $n$-alkanoic acids in Figure 4 differ from those reported in DSDP samples of similar age, but those samples were from locations of higher productivity. In these Leg 72 samples, free alkanoic acid distributions are dominated by $n-\mathrm{C} 16$ and $n$-C18 components and have only small contributions of longer-chain-length acids. Brassell et al. (1980) report free acid distributions in Pleistocene to Miocene samples from DSDP Site 440 in the Japan Trench to be bimodal; contributions of $n-\mathrm{C} 26$ and $n-\mathrm{C} 28$ are larger than those of $n$-C16. Distributions of bound acids from DSDP Site 440 are made up largely of $n-\mathrm{C} 16$, with lesser amounts of $n-\mathrm{C} 14$ and $n-\mathrm{C} 18$ and minor contributions of long-chain acids. In contrast, the bound acids from these Leg 72 samples have important if not major amounts of long-chain components and have bimodal distributions (Fig. 4).

The differences between the fatty acid compositions of Leg 72 samples and those of Leg 56 reported by Brassell et al. (1980) may result from extensive reworking of organic matter in the sediments deposited under a region of low surface productivity in the South Atlantic. Although $n$-C16 and $n$-C18 acids are common to all forms of biota and hence poor source indicators, their dominance suggests important algal or bacterial contributions. The absence of major amounts of longer-chain $n$-C24 to $n-\mathrm{C} 30$ free acids indicates destruction of these terrigenous components because land-derived $n$-alkanes dominate the free hydrocarbon fractions (Fig. 2). Because shorter-chain acids such as $n-\mathrm{C} 16$ are more easily destroyed in sediments than are longer-chain acids (Cranwell, 1981), the presence of relatively large amounts of shorter-chain components in sediments underlying a low- productivity part of the oceans does not indicate algal inputs, but instead indicates bacterial reworking of sediment organic matter and extensive loss of its original character. The bound fraction of acids protects and retains many of its terrigenous components, but their relative contributions may have become exaggerated by loss of shorter-chain acids.

Ratios of $n$-C26 to $n$-C16 acids are given in Table 2, and their low values underscore the dominance of $n-\mathrm{C} 16$ in nearly all of the free and bound distributions. Even/ odd ratios are high, reflecting the relatively large contributions of preserved terrigenous acids in bound fractions and the large amounts of secondary $n-\mathrm{C} 16$ and $n$ $\mathrm{C} 18$ acids of a presumed bacterial origin in both the free and the bound fractions.

\section{Fatty Alcohols}

The distributions of $n$-alkanols shown in Figure 5 are uniformly dominated by $n-\mathrm{C} 22$ with only small contributions of other alcohols. Cranwell (1981) proposes that distributions of this type may result from the activities of decomposer organisms in sediments. Although this hypothesis remains to be verified, it is consistent with other evidence that the organic matter in these Leg 72 sediments is heavily reworked, detrital material.

The C26/C16 $n$-alkanol ratios in Table 2 are variable and difficult to interpret. Even/odd ratios are high because of the dominance of $n-\mathrm{C} 22$. Distributions of free and bound $n$-alkanols extracted from the same sample are very similar (Fig. 5). Such similarity is in contrast to the free and bound fractions of $n$-alkanes (Fig. 2) and $n$-alkanoic acids (Fig. 4), and suggests that the $n$-alkanols in both fractions share a common source.

\section{SUMMARY AND CONCLUSIONS}

1) Low concentrations of organic carbon in Quaternary and Pliocene samples from Sites 515, 516, and 517 indicate that incorporation or organic matter in sediments at these locations took place in oxygenated bottom water conditions and under surface waters having low biological productivity.

2) Distributions of $n$-alkanes are dominated by landplant components that imply important terrigenous contributions to the organic matter contents of these sediments. Because of the bottom morphology at these sites, eolian transport is the most probable input process.

3) Distributions of aliphatic hydrocarbons, $n$-alkanoic acids, and $n$-alkanols contain evidence of microbial reworking of organic components deposited in the sediments at these sites. Bacterial contributions are also evident.

4) The organic matter in these sediments from the Brazil Basin, the Rio Grande Rise, and Vema Channel is heavily reworked, detrital material and is poorly preserved.

\section{ACKNOWLEDGMENTS}

We thank O. E. Kawka for assistance in laboratory analyses, and we appreciate the helpful suggestions to improve this report kindly offered by S. C. Brassell and R. P. Philp. 

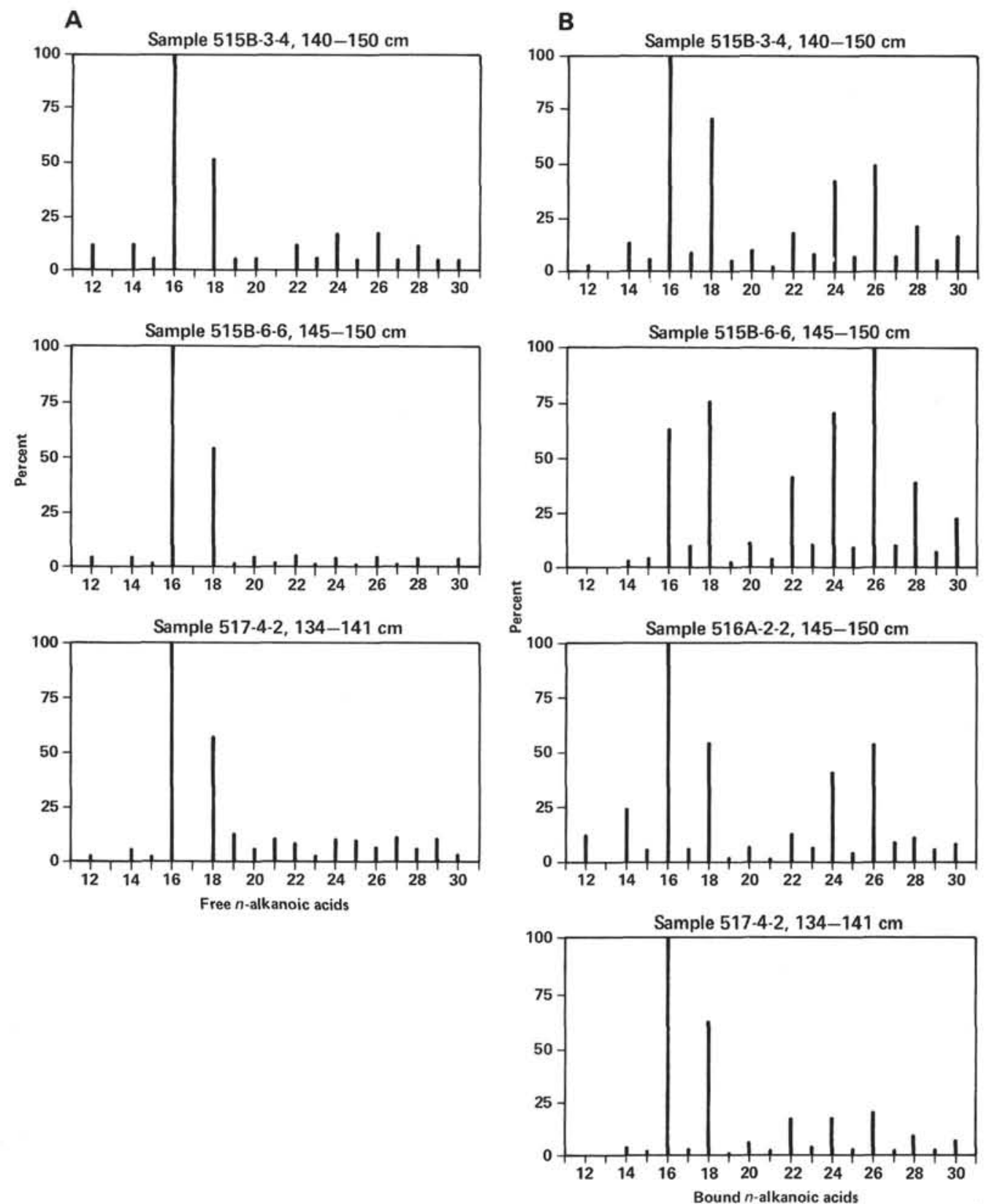

Figure 4. Distributions of free (A) and bound (B) $n$-alkanoic acids normalized to major component and expressed as percentages of that acid.

\section{REFERENCES}

Bishop, J. K. B., Ketten, D. R., and Edmond, J. M., 1978. The chemistry, biology and vertical flux of particulate matter from the upper $400 \mathrm{~m}$ of the Cape Basin in the southeast Atlantic Ocean. Deep-Sea Res., 25:1121-1161.

Boon, J. J., van der Meer, F. W., Schuyl, P. J. W., de Leeuw, J. W., Schenck, P. A., and Burlingame, A. L., 1978. Organic geochemical analyses of core samples from Site 362 , Walvis Ridge, DSDP Leg 40. In Bolli, H. M., Ryan, W. B. F., et al., Init. Repts. DSDP. Suppl. to Vols. $38,39,40$, and 41 : Washington (U.S. Govt. Printing Office), 627-637.

Brassell, S. C., Comet, P. A., Eglinton, G., Isaacson, P. J., McEvoy, J., Maxwell, J. R., Thomson, I. D., Tibbetts, P. J. C., and Volkman, J. K., 1980. Preliminary lipid analyses of Sections 440A-7-6, 440B-3-5, 440B-8-4, 440B-68-2, and 436-11-4: Legs 56 and 57, Deep Sea Drilling Project. In Scientific Party, Init. Repts. DSDP, 56,57, Pt. 2: Washington (U.S. Govt. Printing Office), 1367-1390.
Brassell, S. C., Eglinton, G., and Maxwell, J. R., 1982. Preliminary lipid analyses of two Quaternary sediments from the Middle America Trench, southern Mexico transect, Deep Sea Drilling Project Leg 66. In Watkins, J. S., Moore, J. C., et al., Init. Repts. DSDP, 66: Washington (U.S. Govt. Printing Office), 557-580.

Cobler, R., and Dymond, J., 1980. Sediment trap experiment on the Galapagos spreading center, equatorial Pacific. Science, 209: 801-803.

Cranwell, P. A., 1981. Diagenesis of free and bound lipids in terrestrial detritus deposited in a lacustrine sediment. Org. Geochem., 3: 79-89.

Degens, E. T., and Mopper, K., 1976. Factors controlling the distribution and early diagenesis of organic material in marine sediments. In Riley, J. P., and Chester, R. (Eds.), Chemical Oceanography (Vol. 6): New York (Academic Press), 59-113.

Demaison, G. J., and Moore, G. T., 1980. Anoxic environments and oil source bed genesis. Org. Geochem., 2:9-31. 
Didyk, B. M., Simoneit, B. R. T., Brassell, S. C., and Eglinton, G., 1978. Organic geochemical indicators of palaeoenvironmental conditions of sedimentation. Nature, 272:216-222.

Diester-Haass, L., 1978. Sediments as indicators of upwelling. In Boje, R., and Tomczak, M. (Eds.), Upwelling Ecosystems: Berlin (Springer Verlag), pp. 261-281.

Doran, T., and Johnson, P. G., 1979. Examination of potential geochemical contaminants in Leg 48 material. In Montadert, L., Roberts, D. G., et al., Init. Repts. DSDP, 48: Washington (U.S. Govt. Printing Office), 1157-1160.

Hinga, K. R., Sieburth, J. M., and Heath, G. R., 1979. The supply and use of organic material at the deep-sea floor. J. Mar. Res. 37:557-579.

McEvoy, J., Eglinton, G., and Maxwell, J. R., 1981. Preliminary lipid analyses of sediments from Sections 467-3-3 and 467-97-2. In Yeats, R. S., Haq, B. U., et al., Init. Repts. DSDP, 63: Washington (U.S. Govt. Printing Office), 763-774.

McIver, R., 1975. Hydrocarbon occurrences from JOIDES Deep Sea Drilling Project. Proc. Ninth World Pet. Congr., pp. 269-280.

Müller, P. J., 1977. C/N ratios in Pacific deep-sea sediments: effect of inorganic ammonium and organic nitrogen compounds sorbed by clays. Geochim. Cosmochim. Acta, 41:765-776.

Müller, P. J., and Suess, E., 1979. Productivity, sedimentation rate and sedimentary organic matter in the oceans-I. Organic carbon preservation. Deep-Sea Res., 26A:1347-1362.

Rüllkotter, J., Cornford, C., Flekken, P., and Welte, D. H., 1980. Organic geochemistry of sediments cored during Deep Sea Drilling Project Legs 56 and 57, Japan Trench: Organic petrography and extractable hydrocarbons. In Scientific Party, Init. Repts. DSDP, 56,57, Pt. 2: Washington (U.S. Govt. Printing Office), 1291-1304.

\section{A}
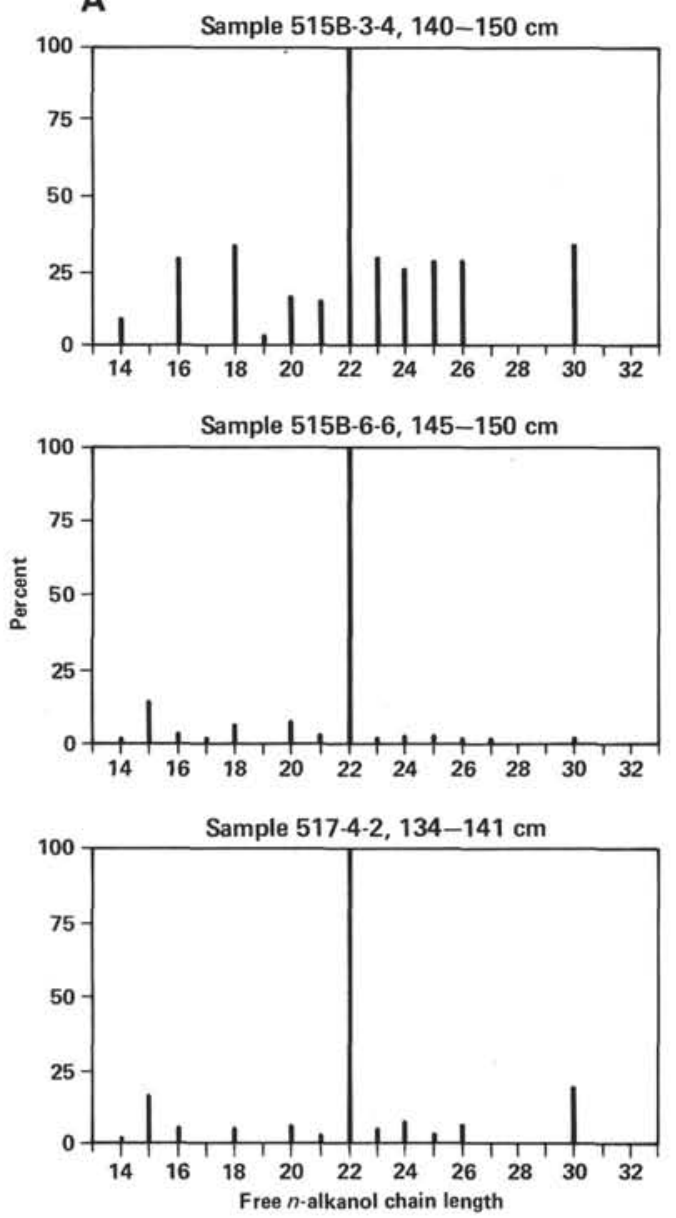

Rüllkotter, J., Flekken, P., and Welte, D. H., 1980. Organic petrography and extractable hydrocarbons of sediments from the northern Philippine Sea, Deep Sea Drilling Project Leg 58. In Klein, G. deV., Kobayashi, K., et al., Init. Repts. DSDP, 58: Washington (U.S. Govt. Printing Office), 755-762.

Rüllkotter, J., von der Dick, H., and Welte, D. H., 1981. Organic petrography and extractable hydrocarbons of sediments from the eastern North Pacific Ocean, Deep Sea Drilling Project Leg 63. In Yeats, R. S., Haq, B. U., et al., Init. Repts. DSDP, 63: Washington (U.S. Govt. Printing Office), 819-836.

Simoneit, B. R. T., 1977. Organic matter in eolian dusts over the Atlantic Ocean. Mar. Chem., 5:443-464.

1978. The organic geochemistry of marine sediments. In Riley, J. P., and Chester, R. (Eds.), Chemical Oceanography (Vol. 7): London (Academic Press), 233-311.

Simoneit, B. R. T., and Mazurek, M. A., 1981. Organic geochemistry of sediments from the Southern California Borderland, Deep Sea Drilling Project Leg 63. In Yeats, R. S., Haq, B. U., et al., Init. Repts. DSDP, 63: Washington (U.S. Govt. Printing Office), 837-853.

Stevenson, F. J., and Cheng, C.-N., 1972. Organic geochemistry of the Argentine Basin sediments: carbon-nitrogen relationships and Quaternary correlations. Geochim. Cosmochim. Acta, 36:653-671.

Suess, E., 1980. Particulate organic carbon flux in the oceans-surface productivity and oxygen utilization. Nature, 288:260-263.

Waples, D. W., and Sloan, J. R., 1980. Carbon and nitrogen diagenesis in deep sea sediments. Geochim. Cosmochim. Acta, 44:1463-1470.

Date of Initial Receipt: October 19, 1982
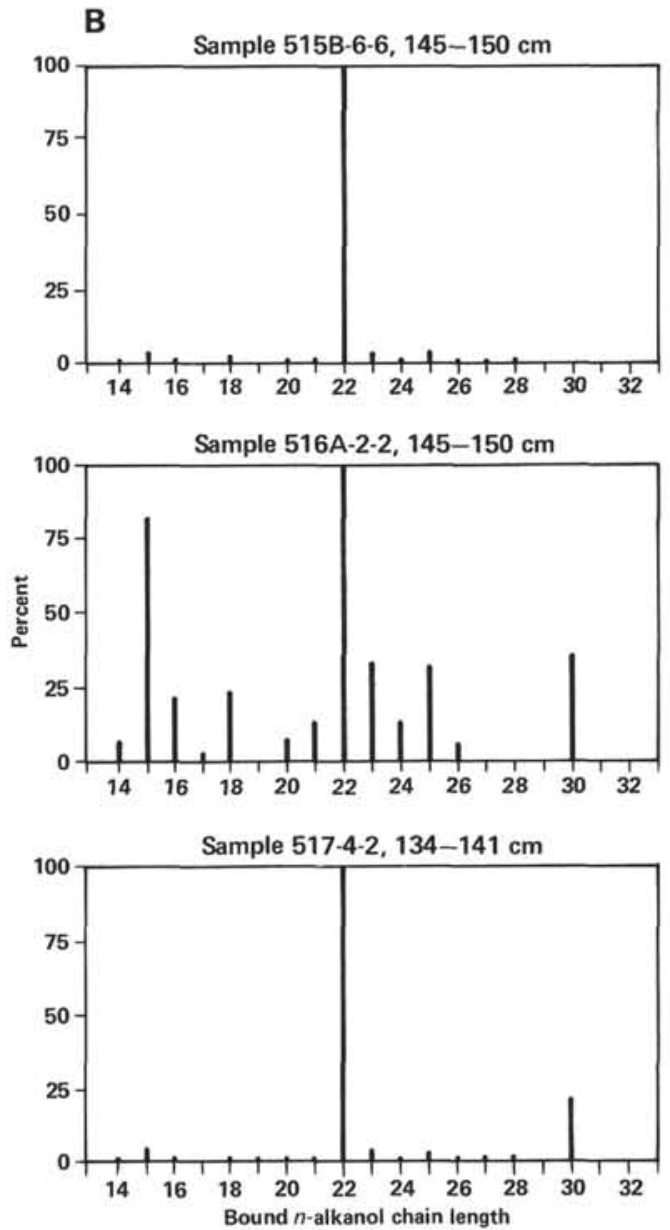

Figure 5. Distributions of free (A) and bound (B) $n$-alkanols normalized to major component, C22, and expressed as percentages of $n-\mathrm{C} 22$. 